\title{
The prevalence of horse trypanosomiasis in Sumba Island, Indonesia and its detection using card agglutination tests
}

\author{
Wisnu Nurcahyo ${ }^{1}$, Marlin R. K. Yowi ${ }^{2}$, Sri Hartati ${ }^{3}$ and Joko Prastowo ${ }^{1}$ \\ 1. Department of Parasitology, Faculty of Veterinary Medicine, Universitas Gadjah Mada, Karangmalang, Yogyakarta \\ 55281, Indonesia; 2. Department of Animal Health, Polytechnic of Agriculture Kupang, Jalan Prof. Herman Yohannes \\ Lasiana, Kupang, Nusa Tenggara Timur, Indonesia; 3. Department of Internal Medicine, Faculty of Veterinary Medicine, \\ Universitas Gadjah Mada, Karangmalang, Yogyakarta, Indonesia. \\ Corresponding author: Wisnu Nurcahyo, e-mail: wisnu-nc@ugm.ac.id \\ Co-authors: MRKY: marlinrambu2015@gmail.com, SH: srihartati.ugm@gmail.com, JP: joko2465@yahoo.com \\ Received: 29-10-2018, Accepted: 13-03-2019, Published online: 09-05-2019
}

doi: 10.14202/vetworld.2019.646-652 How to cite this article: Nurcahyo W, Yowi MRK, Hartati S, Prastowo J (2019) The prevalence of horse trypanosomiasis in Sumba Island, Indonesia and its detection using card agglutination tests, Veterinary World, 12(5): 646-652.

\begin{abstract}
Background and Aim: Horses have a strategic and vital role to play in the lives of the people of Sumba Island, East Nusa Tenggara Province. They act as social animals that are involved in death ceremonies, horse races, and during pasola, thereby supporting tourism, and are given away as dowry in wedding ceremonies. This study aimed to investigate the prevalence of trypanosomiasis among horses in four districts of Sumba Island by examining clinical symptoms and detecting parasites, antibodies, and other factors that are related to Trypanosoma evansi infection in horses.

Materials and Methods: We studied a total of 211 horses that belonged to 88 clinical hobby breeders. Giemsa-colored smears and serum were examined in order to detect antibodies using card-agglutination tests (CATT). The study was conducted during the rainy season that lasted from January to March 2017. Potential risk factors such as the species, sex, origin of the livestock, how the livestock were maintained, and the farmers' knowledge concerning trypanosomiasis were recorded using questionnaires. Data were collected annually for three years from 2010-2012 and repeatedly analyzed by a Chi-square test.

Results: Clinical signs of trypanosomiasis were found in 34 horses; blood smears were examined using Giemsa staining and negative preparations were obtained at a frequency of $0.0 \%(0 / 211)$. The CATT results generally showed that $13.3 \%$ (28/211) of the samples were seropositive for antibodies to T. evansi; the highest percentage, $16.67 \%$ (8/48), of seropositivity was found in the West Sumba District, and the lowest, $12.0 \%(5 / 50)$, was found in Southwest Sumba. The incidence of trypanosomiasis was higher (75\% [21/28]) among female hip horses; horses with 1-5 years of experience were more susceptible to a T. evansi infection (46.4\% [13/28]). In general, farmers on Sumba Island knew of trypanosomiasis (89.8\% $[79 / 88])$, and $69.3 \%(61 / 88)$ of the farmers reported that their livestock was sick. This study was the first serological study conducted on trypanosomiasis in horses of Sumba Island after the surra outbreak in 2010-2012. There were 3\% of farmers who were willing to provide the government with information on implementing a prevention program and controlling the spread of surra on the island.
\end{abstract}

Conclusion: The diagnoses of surra disease were made based on clinical symptoms and parasitological examinations. CATTs could be used to diagnose T. evansi infection in horses.

Keywords: CATT, horses, Sumba Island, Trypanosoma evansi.

\section{Introduction}

Horses have a strategic and vital role to play in the lives of the people of Sumba Island, East Nusa Tenggara Province. They act as social animals that are involved in death ceremonies, horse races, and pasola, thereby supporting tourism, and are given away as dowry during wedding ceremonies. Its vast savannah grassland makes Sumba Island a potential area in Indonesia for breeding livestock, such as horses and cattle. The surra outbreak in Sumba Island occurred

Copyright: Nurcahyo, et al. Open Access. This article is distributed under the terms of the Creative Commons Attribution 4.0 International License (http://creativecommons.org/licenses/ by/4.0/), which permits unrestricted use, distribution, and reproduction in any medium, provided you give appropriate credit to the original author(s) and the source, provide a link to the Creative Commons license, and indicate if changes were made. The Creative Commons Public Domain Dedication waiver (http:// creativecommons.org/publicdomain/zero/1.0/) applies to the data made available in this article, unless otherwise stated. from 2010 to 2012, and the outbreak affected 4268 animals, out of which 1159 animals were horses [1].

Surra is a disease that is caused by Trypanosoma evansi. The disease is almost always fatal to horses. If affected horses are untreated, they can die within 1 week to 6 months. T. evansi-infected horses do not exhibit clinical symptoms [2,3]. T. evansi infections are classified into two types: acute and chronic infections. Typically, the infection lasts for 3 months to 3 years. The clinical symptoms exhibited by animals with trypanosomiasis include urticaria, hemorrhaging in the mucosal membrane, intermittent fever, anemia, edema, icterus, swollen lymph nodes, weakness, paralysis, anorexia, miscarriage, digestive disorders, conjunctivitis, pink eye, hair loss, and body weight loss $[2,4,5]$. The variation in the incidence of surra depends on the sensitivity of animals to the infection and to the presence of host 
vectors such as the Tabanus and Stomoxys spp. The infection causes a significant decrease in reproduction and body weight and an increase in anemia and abortus among domestic Asian, African, and South American species [5].

This study on the prevalence of surra will provide the government with information on implementing a prevention program and controlling the spread of surra on Sumba Island.

This study aimed to investigate the prevalence of trypanosomiasis among horses from four districts of Sumba Island by examining the associated clinical symptoms and by detecting the parasites, antibodies, and other factors related to T. evansi infections in horses.

\section{Materials and Methods}

\section{Ethical approval}

The approval to conduct this study was obtained via the following permissions: permission from the livestock agency of West Sumba with the approval number, 191/K.10/TU/PP/12/2017; a letter of recommendation from Bappeda of Southwest Sumba with the ID, 222/BP.03/12/2017; permission from the agriculture agency of Middle Sumba with the SK number, 188/PP/TU/12/2017; and permission from the agriculture and livestock agency of East Sumba with the SK number, 246/Dinpet/TU/12/2017.

\section{Study areas}

The study was conducted in four districts of Sumba Island, namely West Sumba, Southwest Sumba, Middle Sumba, and East Sumba. The astronomic location of the island is $118^{\circ} 55^{\prime}-120^{\circ} 52^{\prime}$ ' east longitude and $09^{\circ} 16^{\prime}-10^{\circ} 20^{\prime}$ south latitude. The Sumba island is $1,105,242 \mathrm{~km}^{2}$ wide and has a dry climate (semiarid to arid). The districts of Middle Sumba, West Sumba, and Southwest Sumba are wetter than East Sumba. The rainy season is short and lasts for 3-5 months (January-March or December-April) in East Sumba and 4-5 months (December/JanuaryApril) in West Sumba.

\section{Research design and animal samples}

Samples were drawn from horses that were raised extensively and semi-extensively in the period between January to June 2017 using a simple, random sampling technique. The samples were drawn Please define P, Q, and L.for three replications of the tests. The sample size was calculated using the estimated prevalence with the formula: $4 \mathrm{PQ} / \mathrm{L}^{2} . \mathrm{P}=$ Prevalence; $\mathrm{Q}=100-\mathrm{P} ; \mathrm{L}=15 \%$ of $\mathrm{P}$. The prevalence design was based on the prevalence of surra among cattle that was reported on by the Provincial Livestock Service, East Nusa Tenggara, which was $10.28 \%$ out of 152 samples. The samples were assigned to age groups of below 1 year, 1-5 years, and over 5 years. Data, including the sex, age, origin of the livestock, raising system, farmers' knowledge on surra, and awareness of the farmers in terms of reporting a sick animal to a veterinarian, were collected using questionnaires. Data on clinical symptoms related to $T$. evansi infection, including the presence of anemia, body weight loss, neurological disorders such as paralysis, and extremity edema or testicular edema, were collected during sampling.

\section{Specimen collection}

The blood samples were collected from the jugular vein of each animal using a syringe, and they were then stored in vacutainer tubes without heparin. Slanted glass tubes containing blood samples were used to obtain serum. Blood from a syringe was dropped onto an object glass to prepare blood smear slides. Moreover, following this, the slides were dried and fixed using methanol for $3 \mathrm{~min}$ and were then tinted using Giemsa for the parasitological examination. The serum was moved into an Eppendorf tube and stored at $-20^{\circ} \mathrm{C}$ until the antibodies were examined according to the procedure recommended by the Institute of Tropical Medicine, Antwerp, Belgium. At $\mathrm{pH} 7.2,20 \mu \mathrm{l}$ serum was diluted in $60 \mu \mathrm{l}$ phosphate buffer saline using an enzyme-linked immunosorbent assay plate and then homogenized using a "shaker." Approximately, 45 $\mu 1$ of the solution was dropped directly onto the circular card-agglutination test (CATT) cards, and 25 $\mu 1$ serum was added and homogenized using a stirrer. Each CATT card was placed on a rotator; the rotator was switched on at a velocity of $70 \mathrm{rpm}$ for $5 \mathrm{~min}$, and the result was read on a visual display. The specimen was considered positive when the agglutinate turned blue [6].

\section{Statistical analysis}

The prevalence of the disease was estimated by dividing the number of positive samples detected via the CATT by the total number of samples collected from the horses. The prevalence percentage was calculated for Sumba Island as a whole and for each of the districts individually. The risk factors that were associated with surra were reported on descriptively for the entire island and for each district. Data were collected annually via observations conducted between 2010 and 2012 and were analyzed using Chisquare test.

\section{Results}

The clinical symptoms of surra include anemia, body weight loss, neurological disorders such as paralysis, and extremity edema or edema testes (not all the clinical symptoms were found in a single animal). Results of all the blood samples were negative. The highest percentage of seropositive results indicating the presence of surra was found in the West Sumba District, and the lowest was found in the Southwest Sumba District (Figure 1). During the study, the animals were found to be in a poor and seronegative condition, and they did not exhibit any of the clinical symptoms associated with surra. 
Based on the results of the CATTs conducted on horses from Sumba Island (Table-1), the number of seronegative horses was larger than that of seropositive horses in all the districts of Sumba Island $(\mathrm{p}<0.05)$.

Based on the results presented in Table 1, it can be established that there were no significant differences observed in the results of the serological examinations and that the total number of seropositive horses was smaller than that of seronegative horses. The difference was in the sampling location.

According to the CATT results based on the sex of the horses, it was found that the seropositive percentage among the female horses was higher than that among the male horses in all the districts of Sumba Island $(p<0.05)$. The results of the analysis conducted

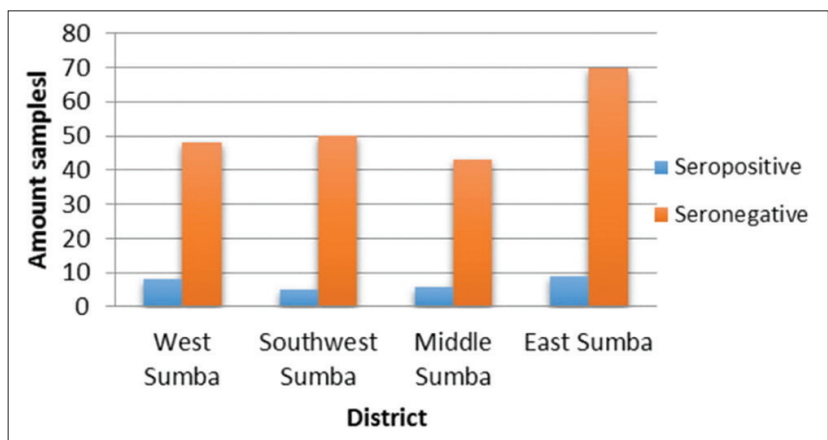

Figure-1: The histogram representing CATT results in four districts of Sumba.

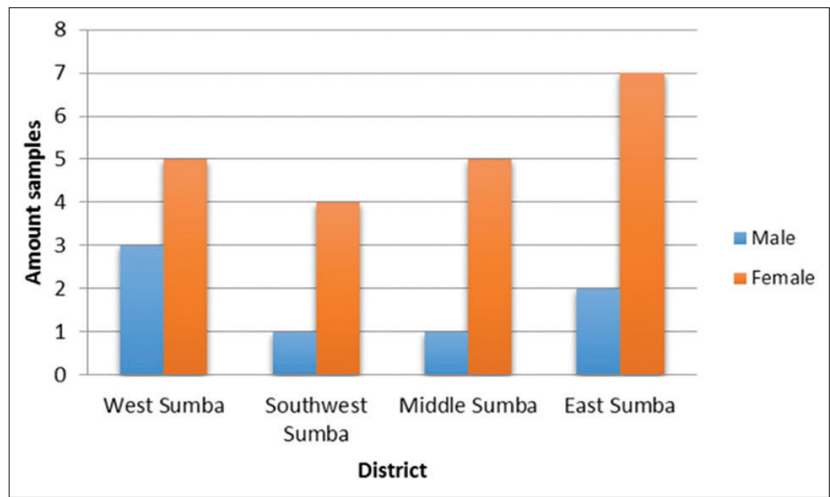

Figure-2: The histogram representing the CATT results based on sex. on the risk factors associated with the surra disease are summarized in Figure-2 and Table-2.

It is evident from the results presented in Table- 2 that there was a significant difference in the serological examination results based on the sex of the animal and that the total number of female horses that were affected was higher than that of male horses. There were no significant differences observed in terms of the sampling location. Mares showed higher surra seropositivity than stallions in all the districts (Figure-2).

The results of the CATTs based on age demonstrated that the horses that were under 1 year old had a lower seropositive percentage than those that were 1-5 years old and those that were above 5 years old in all the districts in Sumba Island $(\mathrm{p}<0.05)$ (Table-3).

It can be clearly observed from the results presented in Table 3 and Figure 3 that the serological examination results based on the age of the animals did not result in significant differences; the total number of seropositive horses under the age of 1 year was lower than the number of those aged between 1-5 years. There were no significant differences in the results in terms of the sampling location.

In general, the adult and old horses were more likely to be more susceptible to a $T$. evansi infection than the young horses were ( $<1$ year) (Figure- 3 ).

The CATT results based on the animals' place of origin showed that the horses that were bought from other locations had a higher seropositive percentage than those that were acquired from their own mothers places of origin, which were Southwest Sumba and West Sumba $(\mathrm{p}<0.05)$. On the contrary, in East and Middle Sumba, the seropositive percentage of the bought horses was lower than that of the horses from their own mothers place of origin $(\mathrm{p}<0.05)($ Table-4).

Based on the data presented in Table 4, it can be established that the horses' origins resulted in significant differences in the serological examination results and that the total number of seropositive horses that were from their own mothers' place of origin was higher than that of those that were bought in a different place of origin. There were

Table-1: CATT results on the prevalence of trypanosomiasis prevalence in four districts of Sumba.

\begin{tabular}{lccc}
\hline Group & Seronegative (\%) & Seropositive (\%) & Chi-square analysis \\
\hline Southwest Sumba & 90 & 10 & $\chi^{2}$ result $=1.98$ \\
West Sumba & 83.30 & 16.70 & $\chi^{2}$ table $=7.81$ \\
East Sumba & 87.1 & 12.9 & $\chi^{2}$ result $<\chi^{2}$ table \\
Middle Sumba & 86.1 & 13.9 & $(\mathrm{p}>0.05)$ \\
\hline
\end{tabular}

Table-2: CATT results on the prevalence of trypanosomiasis based on sex.

\begin{tabular}{lccc}
\hline Group & Male (\%) & Female (\%) & Chi-square analysis \\
\hline Southwest Sumba & 20 & 80 & $\chi^{2}$ result $=13.92$ \\
West Sumba & 37.5 & 62 & $\chi^{2}$ table $=7.81$ \\
East Sumba & 22.2 & 77.8 & $\chi^{2}$ result $>\chi^{2}$ table \\
Middle Sumba & 16.7 & 83.3 & $(p<0.05)$ \\
\hline
\end{tabular}


no significant differences based on the sampling location.

The majority of the horses in East Nusa Tenggara came from their own mothers place of origin when compared to the horses that were bought from places outside the region. The horses that were from the same place of origin as their own mothers were more vulnerable than the horses that were bought for the purposes of dowry or gifts (Figure-4).

The CATT results based on the farming models showed that the seropositivity percentage of the non-pastured horses was higher than that of the pastured ones in all the districts of Sumba Island $(\mathrm{p}<0.05)$ (Table-5).

Based on the data presented in Table-5, it can be established that the horse farm model resulted in significant differences in the serological examination results and that the total number of seropositive

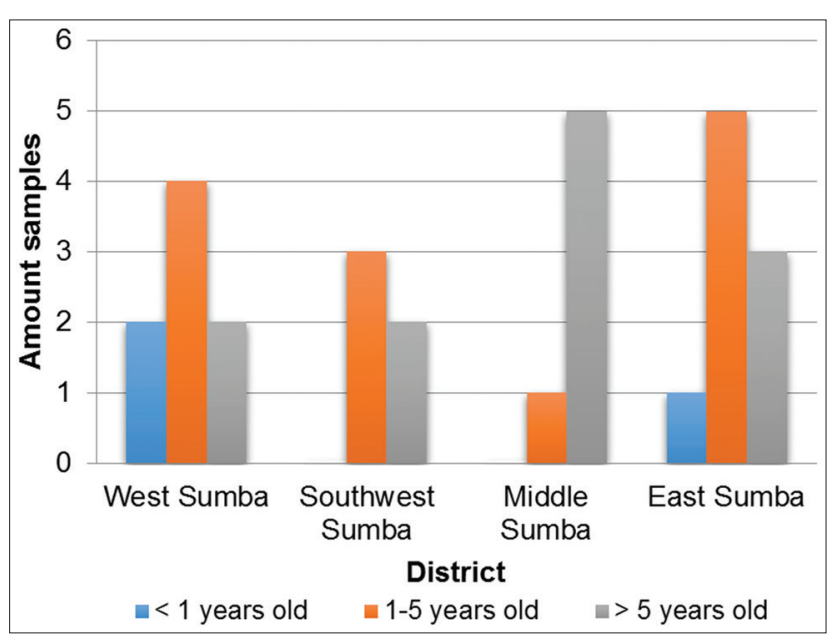

Figure-3: The histogram representing the CATT results based on horse age. non-pastured horses is larger than the number of pastured ones. There were no significant differences based on the sampling location.

There was a larger number of pastured horses in East Nusa Tenggara compared to the number of freerange horses. The pastured horses had higher seropositive percentages associated with surra compared to the free-range horses (Figure-5).

The CATT results based on the farmers' knowledge of trypanosomiasis showed that the seropositivity percentage of the horses owned by farmers who knew about trypanosomiasis was higher than that of the horses owned by farmers who did not know about trypanosomiasis in Southwest Sumba, West Sumba, and East Sumba $(\mathrm{p}<0.05)$. On the contrary, the seropositivity percentage of the horses owned by farmers who knew about trypanosomiasis was lower than that of the horses owned by farmers who did not know

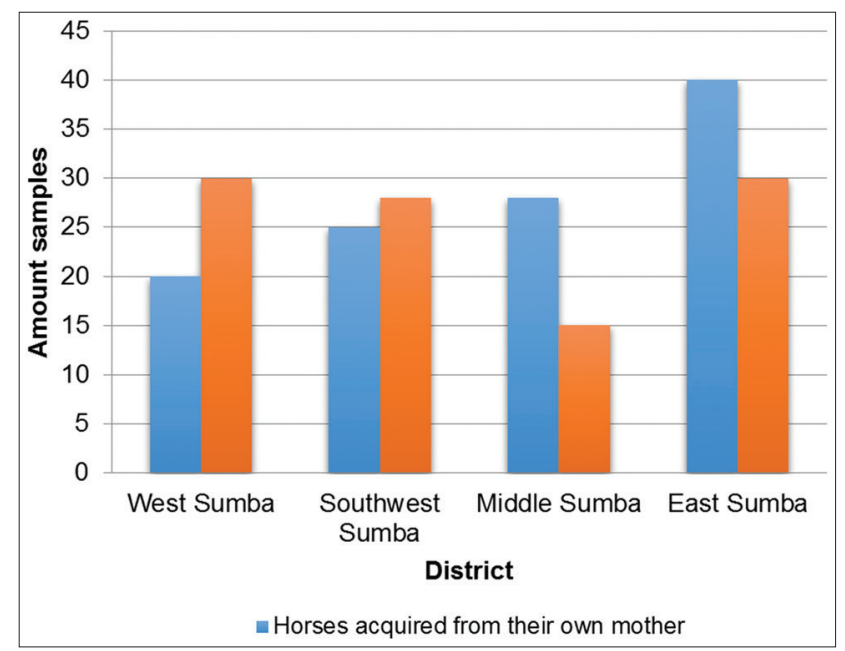

Figure-4: The histogram representing CATT results based on the horses' origins.

Table-3: The CATT results on trypanosomiasis prevalence based on age.

\begin{tabular}{lcccc}
\hline Group & $<\mathbf{1}$ year & $\mathbf{1 - 5}$ years & $\mathbf{> 5}$ years & Chi-square analysis \\
\hline Southwest Sumba & 25 & 50 & 25 & $\chi^{2}$ result $=1.98$ \\
West Sumba & 0 & 60 & 40 & $\chi^{2}$ table $=7.81$ \\
East Sumba & 0 & 16.7 & 83.3 & $\chi^{2}$ result $<\chi^{2}$ table \\
Middle Sumba & 11.12 & 55.55 & 33.33 & $(\mathrm{p}>0.05)$ \\
\hline
\end{tabular}

Table-4: CATT trypanosimiasis results on based on the the animals's origin.

\begin{tabular}{lccc}
\hline Group & $\begin{array}{c}\text { Horses acquired from their own } \\
\text { mother (\%) }\end{array}$ & $\begin{array}{c}\text { Horses acquired via } \\
\text { purchase (\%) }\end{array}$ & $\begin{array}{c}\text { Chi-square } \\
\text { analysis }\end{array}$ \\
\hline Southwest Sumba & 47.16 & 52.84 & $\chi^{2}$ result $=14.64$ \\
West Sumba & 40 & 60 & $\chi^{2}$ table=7.81 \\
East Sumba & 57.15 & 42.85 & $\chi^{2}$ result $>\chi^{2}$ table \\
Middle Sumba & 65.11 & 34.89 & $(p<0.05)$ \\
\hline
\end{tabular}

Table-5: The CATT results on trypanosomiasis baesd on farming models.

\begin{tabular}{lccc}
\hline Group & Pastured (\%) & Non-pastured (\%) & Chi-square analysis \\
\hline Southwest Sumba & 20 & 80 & $\chi^{2}$ result $=13.93$ \\
West Sumba & 37.5 & 62.5 & $\chi^{2}$ table=7.81 \\
East Sumba & 22.2 & 77.8 & $\chi^{2}$ result $>\chi^{2}$ table \\
Middle Sumba & 16.7 & 83.3 & $(p<0.05)$ \\
\hline
\end{tabular}


about trypanosomiasis in Middle Sumba $(\mathrm{p}<0.05)$ (Table-6).

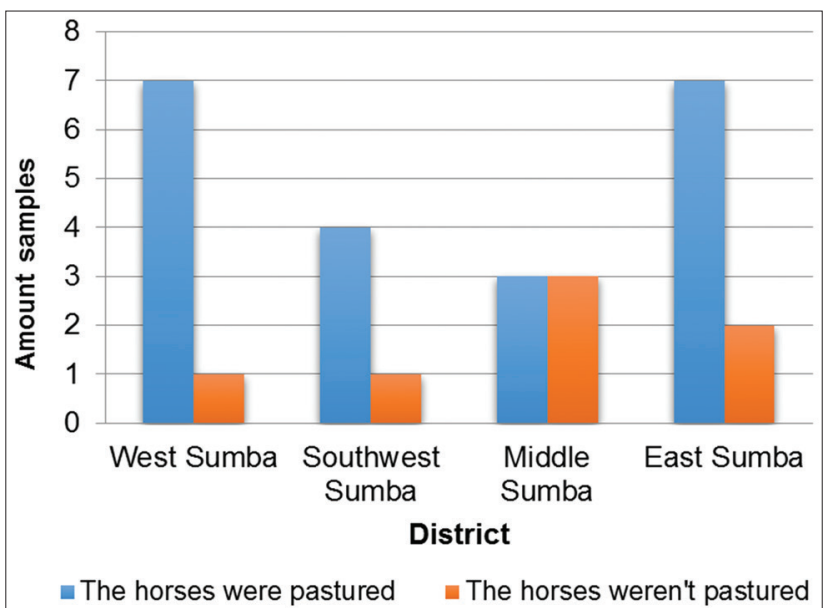

Figure-5: The Histogram representing the CATT results based on farming models.

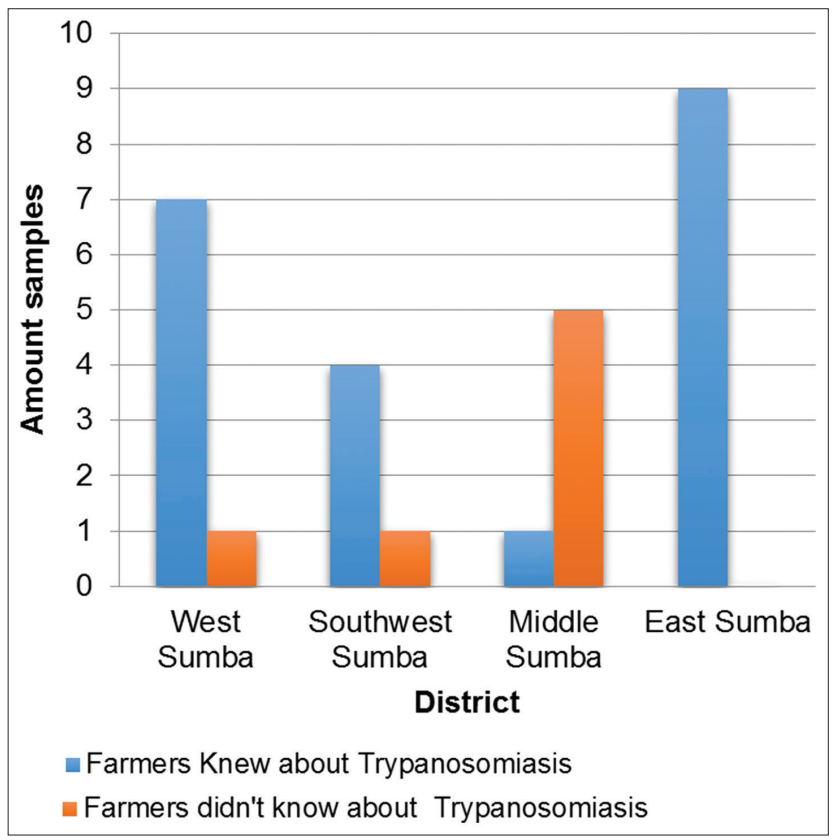

Figure-6: Histogram of CATT results based on farmer trypanposomiasis knowledge.
Based on an ANOVA analysis (Table-6), it can be established that the farmer's knowledge resulted in a significant difference in the serological examination results and that the total number of farmers who knew about trypanosomiasis was larger than that of farmers who did not know about trypanosomiasis. There were no significant differences based on the sampling location.

Among the farmers from the four districts, the farmers from East Sumba had the most knowledge on surra (Figure-6). Horses that were raised by farmers with a higher knowledge level exhibited lower seropositive surra percentages than those raised by farmers with a lower knowledge level.

Data on the willingness of farmers to report their sick animals showed that the seropositivity percentage of horses owned by breeders who reported their sick animals was higher than that of the horses owned by farmers who did not report their sick animals in all the districts in Sumba $(\mathrm{p}<0.05)$ (Table-7).

Based on an ANOVA analysis (Table-7), it can be established that the farmers' awareness in terms of reporting the onset of the disease resulted in significant differences in the serological examination results of their animals; the total number of the farmers who reported that their animals were sick was larger than the number of farmers who did not. There were no significant differences based on the sampling location.

Among the farmers from the four districts, the farmers from Southwest Sumba had the highest level of awareness in terms of reporting the onset of the disease to a veterinarian (Figure-7). The horses raised by these farmers with a high awareness level in terms of reporting the disease onset had a lower seropositive surra percentage than those raised by farmers with a low awareness level.

\section{Discussion}

The diagnostic technique of trypanosomiasis based on examining the clinical symptoms demonstrated a low level of sensitivity. It was allegedly because the horses were in an endemic area with a high incidence of chronic

Table-6: CATT results on trypanosomiasis based on farmer's knowledge.

\begin{tabular}{lccc}
\hline Group & $\begin{array}{c}\text { Farmers knew about } \\
\text { trypanosomiasis (\%) }\end{array}$ & $\begin{array}{c}\text { Farmers did not know about } \\
\text { trypanosomiasis (\%) }\end{array}$ & $\begin{array}{c}\text { Chi-square } \\
\text { analysis }\end{array}$ \\
\hline Southwest Sumba & 62.10 & 37.90 & $\chi^{2}$ result $=224.38$ \\
West Sumba & 95 & 5 & $\chi^{2}$ table $=7.81$ \\
East Sumba & 100 & 0 & $\chi^{2}$ result $>\chi^{2}$ table \\
Middle Sumba & 11.80 & 88.2 & $(\mathrm{p}<0.05)$ \\
\hline
\end{tabular}

Table-7: CATT results based on the farmer's willingness to report sick animals.

\begin{tabular}{lccc}
\hline Group & $\begin{array}{c}\text { Farmers who reported their sick } \\
\text { animals (\%) }\end{array}$ & $\begin{array}{c}\text { Farmers who did not report their } \\
\text { sick animals (\%) }\end{array}$ & $\begin{array}{c}\text { Chi-square } \\
\text { analysis }\end{array}$ \\
\hline Southwest Sumba & 82.80 & 17.20 & $\chi^{2}$ result $=12.54$ \\
West Sumba & 95 & 5 & $\chi^{2}$ table $=7.81$ \\
East Sumba & 95.45 & 4.55 & $\chi^{2}$ result $>\chi^{2}$ table \\
Middle Sumba & 88.20 & 11.8 & $(\mathrm{p}<0.05)$ \\
\hline
\end{tabular}




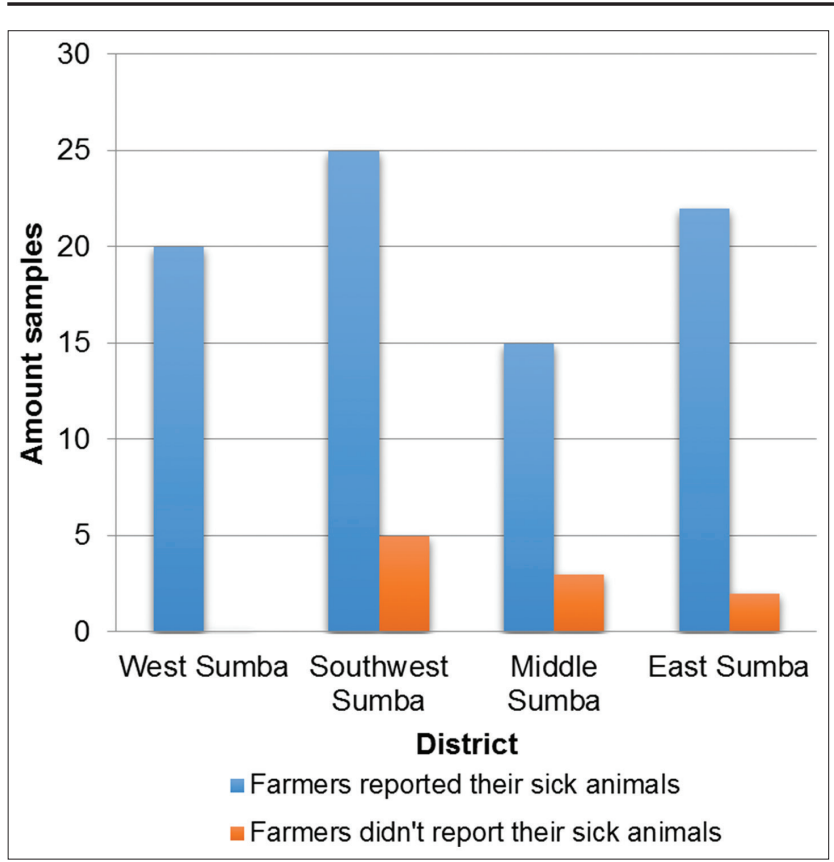

Figure-7: Histogram on the willingness of farmers to report their sick animals.

and subclinical infections. Claes et al. [7] reported that not all the horses that were subclinically infected revealed pathognomonic signs; a serological CATT was used because it had high specificity for T. evansi in horses and is cheap and easy to manage. Horses that are subclinically infected could be potential carriers of the T. evansi infection and could infect other animals that are in close contact with them. The positive results obtained via blood smear slides were allegedly influenced by the timing at which the sampling was conducted, which was in the rainy season [8]. Parasitological examinations carried out using Giemsa tinting of the blood smear slide was the gold standard in diagnosing T. evansi. However, it had low sensitivity. Elamin et al. [9] showed that the incidence of trypanosomiasis in the dry season was higher than in the rainy season. It was considered that this was a result of the increase in the activities of blood-sucking flies in this season. Tehseen et al. [10] reported that a CATT could also be used to aid in the diagnosis of $T$. evansi infections in camels. However, it could not provide information on whether the T. evansi infection was a current infection or a previous one [11]. In general, the percentage of positive CATT results in this study were higher than those generated via the tests carried out by Bill [12] on cattle in the East Nusa Tenggara Province. Furthermore, Mastra [13] studied the prevalence of $T$. evansi antibodies in horses on Sumbawa Island (Bima and Sumbawa Besar district) where horses had a higher mobility than those in the island of Sumba. It was believed that the life phase of mares influenced the susceptibility to $T$. evansi, while pregnancy and lactation could affect the horses' immune system. Sumbria et al. [14] stated that mares were more easily infected by $T$. evansi than stallions. This might relate to pregnancy or lactation [15]. The results of our study on age as a risk factor (Figure 3) were similar to those of the study by Eyob and Matios [16] who stated that horses that were between 1 to 5 years old were more susceptible to the infection than those that were above 5 years or below 1 year old. This was believed to occur because young horses have an adequate level of antibodies needed to fight a T. evansi infection. Meanwhile, Tehseen et al. [17] stated that there were no differences in the ability to fight a T. evansi infection based on a horse's age. In other words, horses of all ages could be infected. The farmers' knowledge of surra was influenced by the surra outbreaks that occurred between 2010 and 2012, during which horse owners in Eastern Sumba began to learn about and understand the disease [18]. Highly knowledgeable farmers were the results of the government's efforts to control the disease by disseminating useful information about surra. The level of a farmer's knowledge generally correlates with their behavior [19]. Farmers who are highly knowledgeable will act proactively if they encounter a sick animal, such as reporting the animals to a veterinarian [20].

\section{Conclusion}

The technique to diagnose surra based on examining the clinical symptoms and conducting parasitological examinations had a low sensitivity level. The CATT can be used to diagnose $T$. evansi infection in horses.

\section{Authors' Contributions}

The study was conceived, arranged, designed, and supervised by WN. MRKY carried out sampling and laboratory analysis. JP, SH, and MRKY analyzed and interpreted the data, while WN did the overall monitoring of the experiment and preparation of the manuscript. All authors read and approved the final manuscript.

\section{Acknowledgments}

The authors would like to thank the Ministry of Research Technology and Higher Education, Indonesia for financial support through DRPM program (contract No. 7230/UN1.PIII/DIT-LIT/LT/2017), Gedung D, Jalan Jenderal Sudirman Pintu Satu, Senayan Jakarta Pusat 10270, Indonesia. Special thanks also to the Head of Livestock official West Sumba city, East Sumba, Middle Sumba, and Southwest Sumba.

\section{Competing Interests}

The authors declare that they have no competing interests.

\section{Publisher's Note}

Veterinary World remains neutral with regard to jurisdictional claims in published institutional affiliation.

\section{References}

1. Dinas Peternakan Kabupaten Sumba Timur. (2015) Laporan Kegiatan Peternakan Tahun 2015. Sumba Timur. Nusa Tenggara Timur.

2. Ng, B.K.Y. and Vancei, B.O.W. (1978) Outbreak of surra in horses and the pathogenesis of anaemia. Kajian Vet., 10(2): 88-98.

3. Desquesnes, M., Holzmuller, P., Lai, D., Dargantes, A., Lun, 
Z. and Jittaplapong, S. (2013) Trypanosoma evansi and surra: a perspective on origin, history, distribution, taxonomy, morphology, host and pathogenic effect. Biomed. Res. Int., (3): 22.

4. Gutierrez, C., Corbera, J.A., Juste, M.C., Doreste, F. and Morales, I. (2006) Clinical, hematological, and biochemical findings in an outbreak of abortion and neonatal mortality associated with Trypanosoma evansi infection in dromedary camels. Ann. N. Y. Acad. Sci., 1081(3): 325-327.

5. Mahmoud, M.E., Abdelfattah, S., Mohamed, M.M. and Eman, K.E.G. (2016) Molecular confirmation of Trypanosoma evansi and Babesia bigemina in cattle from lower Egypt. Pak. Vet. J., 36(4): 409-414.

6. Verloo, D., Magnus, E. and Buscher, P. (2001) General expression of ro tat 1.2 variable antigen type in Trypanosoma evansi isolate from different origin. Vet. Parasitol., 97(3): 183-189.

7. Claes, F., Verloo, D., Maina, M., Urakawa, T., Majiwa, P.A. and Buscher, P. (2005) Recombinant RoTat 1.2 variable surface glycoprotein for diagnosis of Trypanosoma evansi in dromedary camels. Int. J. Parasitol., 35(4): 455-460.

8. Salim, B., Bakheit, M.A. and Sugimoto, C. (2014) Molecular detection of equine trypanosomes in the Sudan. Vet. Parasitol., 200(3-4): 246-250.

9. Elamin, E.A., el Bashir, M.O. and Saeed, E.M. (1998) Prevalence and infection pattern of Trypanosoma evansi in camels in mid-eastern Sudan. Trop. Anim. Health Prod., 30(2): 107-114.

10. Tehseen, S., Jahan, N., Qamar, M.F., Desquesnes, M. and Shahzad, M.I. (2015) Parasitological, serological and molecular survey of Trypanosoma evansi infection in dromedary camels from Cholistan desert, Pakistan. Parasit. Vectors, 8(1): 415.

11. Ismael, A., Swelum, A.A., Khalaf, A.F. and Abouheif, M.A. (2014) Clinical, haematological and biochemical alterations associated with an outbreak of theileriosis in dromedaries (Camelus dromedarius) in Saudi Arabia. Pak. Vet. J., 34(2): 209-213.
12. Luckins, A.G. (1988) Trypanosoma evansi in Asia. Parasitol. Today, 4(5): 137-142.

13. Mastra, I.K. (2011) Seroprevalensi trypanosomiasis di pulau sumba, provinsi nusa tenggara barat. Bull. Vet., 23(79): 131-138.

14. Sumbria, D., Singla, L.D., Sharma, A., Moudgil, A.D. and Bal, M.S. (2014) Equine trypanosomiasis in central and western Punjab: prevalence, hemato-biochemical response and associated risk factors. Acta Trop., 138(6): 44-50.

15. Ahmed, A.R. (2008) Epidemiological studies (parasitological, serological and molecular techniques) of Trypanosoma evansi infection in camels (Camelus dromedarius) in Egypt. Vet. World, 1(11): 325-328.

16. Eyob, E. and Matios, L. (2013) Review on camel trypanosomiasis (Surra) due to Trypanosoma evansi: epidemiology and host response. J. Vet. Med. Anim. Health, 5(12): 334-343.

17. Tehseen, S., Jahan, N., Qamar, M.F., Shahzad, M.I. and Desquesnes, M. (2016) Field investigation of Trypanosoma evansi and comparative analysis of diagnostic tests in horses from Bahawalpur, Pakistan. Turk. J. Vet. Anim. Sci., 40(2): 141-146.

18. Bili, F.A.L. (2014) Seroprevalensi Trypanosomiasis (Surra) di Wilayah Nusa Tenggara Timur. Prosiding, Vol. 1 No.5. Penyidikan Penyakit Hewan. Rapat Teknis dan Pertemuan Ilmiah (RATEKPIL) Surveilans Kesehatan Hewan. Dirkeswan-Ditjen Peternakan dan Kesehatan Hewan, Kementerian Pertanian.

19. Bhutto, B., Gadahi, J., Shah, G., Dewani, P. and Arijo, A. (2010) Field investigation on the prevalence of trypanosomiasis in camels in relation to sex, age, breed and herd size. Pak. Vet. J., 30(3): 175-177.

20. Anonymous (2014) Pedoman Pengendalian dan Pemberantasan Penyakit Trypanosomiasis (Surra). Direktorat Kesehatan Hewan, Direktorat Jenderal Peternakan dan Kesehatan Hewan Kementerian Pertanian. 